\title{
Lipid Screening, Extraction and Production of Biodiesel from Marine Diatom Odontella aurita
}

\author{
Shailesh Upadhyay ${ }^{1}$, Kapil Lawrence ${ }^{1}$, Sudhir K. Shekhar ${ }^{2}$ and P. Anantharaman ${ }^{3}$ \\ ${ }^{1}$ Department of Biochemistry and Biochemical Engineering, JSBB, SHIATS, Allahabad, India \\ ${ }^{2}$ Department of Biotechnology, Babasaheb Bhimrao Ambedkar University \\ (A Central University), Lucknow, India \\ ${ }^{3} \mathrm{CAS}$ in Marine Biology, Annamalai University, Parangipettai, Tamilnadu, India \\ *Corresponding author
}

\section{A B S T R A C T}

\begin{tabular}{l}
\hline K e y w o r d s \\
Odontella aurita, \\
Lipid, Si, \\
Transesterification, \\
GC-MS, \\
Biodiesel and SEM. \\
\hline Article Info \\
\hline $\begin{array}{l}\text { Accepted: } \\
\text { 20 February } 2017 \\
\text { Available Online: } \\
\text { 10 March } 2017\end{array}$ \\
\hline
\end{tabular}

The marine diatom based biodiesel may be the greatest possible options for future energy, particularly for India where land resources and freshwater are limited. In the above context, an attempt has been made to isolate the marine diatom Odontella aurita from Vellar estuary, South east coast of India and characterized for biodiesel production. Identification of microscopic structure, morphology was succeeding by bright field microscope and SEM. In the present study, the effect of different Si treatment on the growth and lipid content confirmed that the cell density is maximum at $159 \mu \mathrm{M}$ Si medium $10.21 \pm 0.16 \times 10^{5}$ cells $\mathrm{ml}^{-1}$ and minimum at $0 \mu \mathrm{M} \mathrm{Si}$ medium (medium without $\mathrm{Si}$ ) $5.5 \pm 0.10 \times 10^{5}$ cells $\mathrm{ml}^{-1}$, accumulation of lipid content maximum at $53 \mu \mathrm{M}$ Si medium $23.7 \pm 79 \%$ of dry biomass were minimum $13.25 \pm 76 \%$ of dry biomass at $159 \mu \mathrm{M} \mathrm{Si}$ medium. Fatty Acid Methyl Esters (FAME) produced by transesterification of lipid obtained at $53 \mu \mathrm{M}$ Si medium Results show that among the fatty acids, saturated fatty acid (SFAs) was found to be $43.61 \%$ followed by monounsaturated fatty acid $(33.22 \%)$ and polyunsaturated fatty acid $(23.17 \%)$. From the above results, it is concluded that $O$. aurita species having low percentage of polyunsaturated fatty acids and higher percentage of saturated fatty acid that could be suitable for further exploration and commercial biodiesel production.

\section{Introduction}

Diatoms are important primary producers due to their high lipid content and are widely distributed in most aquatic habitats. They are unicellular photosynthetic eukaryotes within the class Bacillariophyceae. A peculiar feature of diatoms compared to other microalgae is their siliceous cell wall. The numbers of their genera and species are approximately 250 and 100,000, respectively (Lebeau and Robert, 2003), and they are a staple food for many zooplankton, shellfish and shrimp larvae, and even small fish. For example, diatoms are the main food source for post-larvae abalone (Hahn, 1989) and monospecific cultures of benthic diatoms have successfully been employed as feed for the culture of post-larvae abalone (Chen, 2007; Hillebrand and Sommer, 2000).

Green algae and diatoms are high in neutral lipids, accounting for nearly $70 \%$ of their total lipids (Borowitzka, 1988), but only a small 
percentage of green algal species exhibit a high total lipid content; therefore, diatoms represent the best oil producer among these species. The main products of diatom photosynthesis are chrysolaminarin and lipids. The accumulation of lipids varies within different diatom species, growth stages and environments (Chen, 2012).

Biodiesel is a renewable energy and can be produced from a variety of sources, including plants, animals and microbes (Williams and Laurens, 2010). Biodiesel is commonly produced by transesterification of triglycerides from vegetable oils with methanol obtaining fatty acid methyl esters (FAMEs) (Vicente, 2009). However, high manufacturing cost and the majority of raw materials such as vegetables oils which struggle with the food industry and need a very large percentage of the current available land are some disadvantages for biodiesel production (Ahmad et al., 2011). Oil from photosynthetic microorganisms such as microalgae has emerged as one of the most capable substitute sources of lipids to be used in biodiesel production because of its fast growth rates, cost effective photosynthesis and less competition for agricultural land when compared to conventional vegetable oil crops (Subbramaniam et al., 2010).

Microalgal strains for liquid biodisel production should ideally show very high biomass productivities, efficient biosynthesis of lipids, be easy to harvest and be accessible to metabolic engineering strategies (Chisti, 2007). Furthermore, important characteristics for renewable liquid biofuel production include storage of lipid and the degree of saturation of fatty (Aatola et al., 2008; Mata et al., 2010). Both parameters can be highly influenced by various factors, e.g. the presence or absence of specific nutrients like silicate ( $\mathrm{Si})$, depending on the respective strains (Hu et al., 2008). Diatoms are one of the largest groups of silicifying organisms and most species have an obligate requirement for Si for cell wall formation. This characteristic means that in addition to modifying nutrients in the media to induce lipid formation (Jiang et al., 2012; Kwon et al., 2013).

Considering the above context and need of a new source for biodiesel production, the present study was aimed to isolate, identify and characterize nutrient ( $\mathrm{Si}$ ) for the potential ability of Odontella aurita to produce lipid for the production of biodiesel.

\section{Material and Methods}

\section{Isolation and Identification of marine diatom}

The marine diatom, Odontella aurita was collected from Vellar estuary, Prangipeettai, Tamilnadu, Southeast coast of India (Bay of Bengal) with the Latitude $11^{\circ} 29^{\prime} \mathrm{N}$ and Longitude $79^{\circ} 46^{\prime} \mathrm{E}$. The diatom collection was done by horizontal towing of phytoplankton net (No-30, bolting silk cloth, $45 \mu \mathrm{m})$ during early morning by following the method of Mohan et al., (2012). The individual diatom strain was isolated using serial dilution. Then the isolated pure cultures were maintained in Guilard, f/2 (1975) medium. The diatom was examined under a zoom stereomicroscope (Olympus). The diatom was identified according to their morphological characteristics with help of standard taxonomic references as previously described by Thomas (1997); Venkataraman (1939); Subrahmanyan (1946).

\section{Cultivation of diatom and determination of cell density}

The isolated diatom was cultivated in Guilard, $\mathrm{f} / 2$ (1975) medium. All the experiments were conducted in 5 litre conical flasks. The culture was provided with 12:12 dark: light cycle 
with 4500 lux white fluorescent lamp at temperature $25^{\circ} \mathrm{C} \pm 2^{\circ} \mathrm{C}$. Then the strains were examined daily for the contamination. The cell density of the isolated species was determined using a $0.1 \mathrm{~mm}$ deep Neubauer chamber. In this study four Si treatments were evaluated, treatment 1(T1) consisted of the standard f/2medium without Si $(0 \mu \mathrm{M} \mathrm{Si}), \mathrm{T} 2$ consisted f/2 medium with reduced Si $(53 \mu \mathrm{M}$ $\mathrm{Si}$ ), T3 consisted $\mathrm{f} / 2$ medium (Si $106 \mu \mathrm{M}$ ), T4 consisted $\mathrm{f} / 2$ medium with increased $\mathrm{Si}$ (159 $\mu \mathrm{M} \mathrm{Si}$ ), T3 treated as control, all treatments taken in triplicate. All data show in mean value. In all treatments were used to study the effect of Si on cell density and lipid content. Treatment having maximum lipid yield was further used for transesterification and GCMS analysis.

\section{Determination of lipid content}

The culture was grown at different $\mathrm{Si}$ treatment such as T1, T2, T3 and T4, lipid estimation was done by the method previously described by Floch et al., (1956). One gram dry algal sample homogenized with $20 \mathrm{ml}$ of chloroform/methanol (2/1). After dispersion, the whole mixture is agitated during 15-20 min in an orbital shaker at room temperature. Then the homogenate was filtered using Wattman no.1 filter paper), and the solvent is washed with 0.2 volumes $(4 \mathrm{ml}$ for $20 \mathrm{ml}$ ) of water or better $0.9 \% \mathrm{NaCl}$ solution. After vortexing, the mixture was centrifuged at low speed (2000 rpm) to separate the two phases.

\section{Transesterification of lipid and FAME analysis}

The algal lipid extracted from treatment T2 ( $\mathrm{Si}$ concentration $53 \mu \mathrm{M}$ ) was used for transesterification into fatty acid methyl ester (FAME) by following the procedure previously described by Ichihara et al., (1996). Briefly, $10 \mathrm{mg}$ of lipid was dissolved in $2 \mathrm{ml}$ of hexane and $200 \mu \mathrm{l}$ of $2 \mathrm{M}$ methanolic $\mathrm{KOH}$ (used as catalyst). Mixture was vortexed for 2-5 min followed by a brief centrifugation. The upper hexane layer was collected for FAME analysis. Quantification of FAME was carried out using gas chromatography.

\section{GC/MS analysis}

The fatty acid composition was analyzed using GC-MS. The GC-MS analysis was carried out using an Agilent 6890N gas chromatography connected to an Agilent 5973 mass selective detector at $70 \mathrm{EV}(\mathrm{m} / \mathrm{z} \mathrm{50}$ 550; sources at $230{ }^{\circ} \mathrm{C}$ and quadruple at $150^{\circ} \mathrm{C}$ ) in the electron impact mode with a HP-5 capillary column $(30 \mathrm{~m} \times 0.25 \mathrm{~mm}$ i.d. $\times \quad 0.25 \mu \mathrm{m}$ film thickness). The oven temperature was programmed for $2 \mathrm{~min}$ at $160{ }^{\circ} \mathrm{C}$ and raised to $300{ }^{\circ} \mathrm{C}$ at $5^{\circ} \mathrm{C} \mathrm{min}{ }^{-1}$ and maintained for $20 \mathrm{~min}$ at $300{ }^{\circ} \mathrm{C}$. The carrier gas helium was used at a flow rate of $1.0 \mathrm{ml}$ $\min ^{-1}$. The inlet temperature was maintained at $300{ }^{\circ} \mathrm{C}$ with a split ratio of 50:1. The injection volume was $1 \mu \mathrm{l}$, with a split ratio of 50:1.

\section{Results and Discussion}

\section{Isolation and identification of diatoms}

Marine diatom was isolated from the Vellar estuary Southeast coast of India and identified as $O$. aurita by morphologically. O. aurita were cultivated in different $\mathrm{Si}$ concentration (T1, T2, T3 and T4 Treatment) Guilard, f/2 (1975) medium. Microscopic structre and morphology of $O$. aurita was observed by bright field microsope and scaning electron microscopy (SEM) shown in (Fig. 1), Lifeform: Cells united in chains and often on substrate, Size: Diameter $=10-95 \mu \mathrm{m}$.

\section{Growth curve at different treatment}

Figure 2 shows the growth curve O.aurita at four different Si treatments. From this figure, 
it can be observed that day 4 shows the highest growth compared to other days. $O$. aurita was experienced the maximum cell density at $11^{\text {th }}$ day in T3 treatment and T4 treatment medium. Figure 3 Show that initial three days growth slow in all treatment medium.

The objective of growth curve of $O$. aurita in different Si medium was observe its growth trend with different Si concentration medium and optimized conditions. Under laboratory cultured conditions, $O$. aurita showed a short lag phase that has lasting about 24 hour in in all medium. Subsequently, cells grew actively from day 3 untill day 9, whereas increasses growth rate highest in $4^{\text {th }}$ day compared to other day. During this time cell is doubling and the number of new microalgae appering per day is proportional to the present population. On day 10 untill day 13 At this phase, the growth of cells were entered stationary phase.

Therefore based on growth highest growth in T4 medium (Si concentration $106 \mu \mathrm{M}$ ) while lowest in $\mathrm{T} 1$ medium ( $\mathrm{Si}$ concentration 0 $\mu \mathrm{M})$. Figre 2 show that maximum cell density were $10.21 \pm 0.16 \times 10^{5}$ cells $\mathrm{ml}^{-1}$ at treatment $\mathrm{T} 4 \quad(\mathrm{Si}$ concentration $159 \mu \mathrm{M}$ ) while minimum cell density $5.5 \pm 0.10 \times 10^{5}$ cells ml ${ }^{1}$ at treatment $\mathrm{T} 1$ ( $\mathrm{Si}$ concentration $0 \mu \mathrm{M}$ ), treatment $\mathrm{T} 2$ and treatment $\mathrm{T} 3$ cell density $6.6 \pm 0.22 \times 10^{5}$ and $7.95 \pm 0.20 \times 10^{5}{\text { cells } \mathrm{ml}^{-1}}^{-1}$ respectively.

The total lipid content at various Si treatments is shown in figure (4). Lipid content was varying at different $\mathrm{Si}$ treatments. It was found to be maximum $23.70 \pm 0.79 \%$ of dry biomass in treatment $\mathrm{T} 2$ ( $\mathrm{Si}$ concentration 53 $\mu \mathrm{M})$ and minimum $13.25 \pm 0.33 \%$ of dry biomass in treatment $\mathrm{T} 4$ ( $\mathrm{Si}$ concentration 159 $\mu \mathrm{M}$ ). Treatment $\mathrm{T} 1$ and T3 (control) lipid content $19.10 \pm 0.28 \%$ and $15.40 \pm 0.40 \%$ of dry biomass respectively.

\section{FAME analysis}

Lipid content found maximum in treatment (T2) further this lipid used for transesterification. FAME analysis was done by GC-MS, shown in different peaks area and RT in chromatogram (Fig. 5, Table 1).

The fatty acid profile of stationary phase culture of $O$. aurita is shown in Table 2. The percentage of SFAs was found to be $43.61 \%$ in the lipid fraction which was higher than Monounsaturated fatty acids (MUFAs) $(33.22 \%)$. Both classes of fatty acid were higher than polyunsaturated fatty acids (PUFAs) 23.17\%). Myristic acid (C14:0), palmitic acid (C16:0) and stearic acid (C18:0) were found to be the most abundant SFAs. Furthermore, the pentadecanoic acid (C15:0). Pentadecanoic acid accounted for $0.75 \%$. Palmitoleic acid (C16:1n7) and oleic acid (C18:1 n-9cis) were the predominant MUFAs. Furthermore, 11-Eicosenoic acid accounted for $3.49 \%$. PUFAs were essentially composed of linoleic acid (C18:2 n6cis), alpha-linolenic acid (18:3 n-6) and Methyl arachidonate (C20:4) were most abundant PUFAs.

The growth and lipid content are the two significant components for the biodiesel production that have been quantified for a wide variety of microalgae. In the present study, the accumulation of lipid was found to be varying in $O$. aurita at different $\mathrm{Si}$ content medium. It is corresponds to the previous report of Guschina and Harwood (2006), they have reported, lipid and fatty acid composition in microalgae is species or strain specific and varies with different culture conditions.

O. aurita showed a short lag phase that has lasting about 24 hour in all $\mathrm{Si}$ treatment medium. Subsequently, cells grew actively from day 3 untill day 9, whereas increasses growth rate highest in $4^{\text {th }}$ day compared to 
other day. After $10^{\text {th }}$ day cells entered into stationary phase, at this phase growth rate slows as a result of nutrient depletion and accumulation of toxic products. In this phase, microalgae begin to exhaust the resources that are availble to them. In day 13 it can be observed that cells undergoes dead phase whereas microalgae was run out of nutrients and die off. The most important parameter regulating algal growth are nutrient quality and quantity (Jalal et al., 2012). This growth pattern were simillar to result repored by Jalal et al., (2012) in Isochyris sp. Hemalatha et al.,
(2014). Similarly reported in Chaetoceros simplex that maximum cell density was reached in $212 \mu \mathrm{M}$ silicate concentration followed by $159 \mu \mathrm{M}$ in 10 days aged culture. Lower concentration $(50 \%$ of $\mathrm{f} / 2$ concentration) shown minimum cell count and actual $\mathrm{f} / 2$ media concentration $(106 \mu \mathrm{M})$ shown medium cell density than other high concentrations of silicate (Ramirez et al., 2015) achieved maximum cell density $\left(719200 \pm 116895\right.$ cells ml $\left.^{-1}\right), \mathrm{f} / 2$ medium with double silicate $(1085600 \pm 84639$ cells $\mathrm{ml}^{-1}$ ) in Nitzschia epithemioides.

Table.1 RT according to peak area

\begin{tabular}{|c|c|c|c|c|c|c|}
\hline Peak\# & R.Time & I.Time & F.Time & Area & Area\% & Name \\
\hline 1 & 8.627 & 8.572 & 8.718 & 2632675 & 9.57 & $\begin{array}{l}\text { Tetradecanoic acid, methyl ester (CAS) Methyl } \\
\text { myristate }\end{array}$ \\
\hline 2 & 9.035 & 8.982 & 9.086 & 203571 & 0.74 & $\begin{array}{l}\text { Octadecanoic acid, methyl ester (CAS) Methyl } \\
\text { stearate }\end{array}$ \\
\hline 3 & 9.481 & 9.430 & 9.523 & 206322 & 0.75 & Pentadecanoic acid, methyl ester \\
\hline 4 & 10.430 & 10.363 & 10.515 & 7075485 & 25.72 & $\begin{array}{l}\text { Hexadecanoic acid, methyl ester (CAS) Methyl } \\
\text { palmitate }\end{array}$ \\
\hline 5 & 10.982 & 10.912 & 11.040 & 2396091 & 8.71 & $\begin{array}{l}\text { 9-Hexadecenoic acid, methyl ester, (Z)- (CAS) } \\
\text { Methyl palmitoleate }\end{array}$ \\
\hline 6 & 12.542 & 11.481 & 12.615 & 1878910 & 6.83 & $\begin{array}{l}\text { Octadecanoic acid, methyl ester (CAS) Methyl } \\
\text { stearate }\end{array}$ \\
\hline 7 & 12.877 & 12.819 & 12.953 & 596960 & 2.17 & $\begin{array}{l}\text { 6-Octadecenoic acid, methyl ester (CAS) Methyl 6- } \\
\text { octadecenoate }\end{array}$ \\
\hline 8 & 13.071 & 12.953 & 13.123 & 3994403 & 14.52 & 9-Octadecenoic acid (Z)-, methyl ester \\
\hline 9 & 13.170 & 13.123 & 13.228 & 987597 & 3.59 & 9-Octadecenoic acid (Z)-, methyl ester \\
\hline 10 & 13.889 & 13.846 & 13.963 & 2894016 & 10.52 & 9,12-Octadecadienoic acid (Z,Z)-, methyl ester \\
\hline 11 & 14.470 & 14.406 & 14.528 & 209074 & 0.76 & 6,9,12-Octadecatrienoic acid, methyl ester (CAS) \\
\hline 12 & 14.881 & 14.820 & 14.937 & 715251 & 2.60 & 7,10,13-Hexadecatrienoic acid, methyl ester (CAS) \\
\hline 13 & 15.360 & 15.275 & 15.415 & 960087 & 3.49 & 11-Eicosenoic acid, methyl ester (CAS) \\
\hline 14 & 15.473 & 15.415 & 15.538 & 684991 & 2.49 & $\begin{array}{l}\text { 9,12,15-Octadecatrienoic acid, methyl ester, } \\
\text { (Z,Z,Z)- (CAS) }\end{array}$ \\
\hline 15 & 16.214 & 16.168 & 16.249 & 184315 & 0.67 & $\begin{array}{l}\text { OCTADECA-9,12-DIENOIC ACID } \\
\text { ESTER }\end{array}$ \\
\hline 16 & 16.824 & 16.780 & 16.891 & 222828 & 0.81 & $\begin{array}{l}\text { 7,10,13-Eicosatrienoic acid, methyl ester (CAS) } \\
\text { METHYL }\end{array}$ \\
\hline 17 & 17.253 & 17.200 & 17.328 & 885811 & 3.22 & Methyl arachidonate \\
\hline 18 & 17.710 & 17.672 & 17.754 & 203571 & 0.74 & $\begin{array}{l}\text { 9-Octadecenoic acid (Z)-, methyl ester (CAS) } \\
\text { Methyl oleate }\end{array}$ \\
\hline \multirow[t]{2}{*}{19} & 17.908 & 17.865 & 17.964 & 577703 & 2.10 & $\begin{array}{l}\text { 9,12,15-Octadecatrienoic acid, methyl ester, } \\
(\mathrm{Z}, \mathrm{Z}, \mathrm{Z})\end{array}$ \\
\hline & & & & 27509661 & 100.00 & \\
\hline
\end{tabular}


Table.2 displays the fatty acid profile of Odontella aurita at T2 treatment

\begin{tabular}{|c|c|c|c|}
\hline Systemic name of FAME & Formula & $\begin{array}{l}\text { Fatty acid content } \\
\text { (\%total FAME) }\end{array}$ & Family \\
\hline Tetradecanoic acid, methyl ester & $\mathrm{C}_{15} \mathrm{H}_{30} \mathrm{O}_{2}$ & 9.57 & SFA \\
\hline Pentadecanoic acid, methyl ester & $\mathrm{C}_{16} \mathrm{H}_{32} \mathrm{O}_{2}$ & 0.75 & SFA \\
\hline Hexadecanoic acid, methyl ester & $\mathrm{C}_{17} \mathrm{H} 34 \mathrm{O} 2$ & 25.72 & SFA \\
\hline Octadecanoic acid, methyl ester & $\mathrm{C} 19 \mathrm{H} 38 \mathrm{O} 2$ & 7.57 & SFA \\
\hline \multicolumn{4}{|c|}{ Total SFA - $\quad 43.61$} \\
\hline 6-Octadecenoic acid, methyl ester & $\mathrm{C} 19 \mathrm{H} 36 \mathrm{O} 2$ & 2.17 & MUFA \\
\hline 9-Octadecenoic acid (Z)-, methyl ester & $\mathrm{C} 19 \mathrm{H} 36 \mathrm{O} 2$ & 18.85 & MUFA \\
\hline 9-Hexadecenoic acid, methyl ester, (Z)- & $\mathrm{C} 17 \mathrm{H} 32 \mathrm{O} 2$ & 8.71 & MUFA \\
\hline 11-Eicosenoic acid, methyl ester & $\mathrm{C} 21 \mathrm{H} 40 \mathrm{O} 2$ & 3.49 & MUFA \\
\hline \multicolumn{4}{|c|}{ Total MUFA - $\quad 33.22$} \\
\hline 7,10,13-Hexadecatrienoic acid, methyl ester & $\mathrm{C} 17 \mathrm{H} 28 \mathrm{O} 2$ & 2.60 & PUFA \\
\hline 6,9,12-Octadecatrienoic acid, methyl ester & $\mathrm{C} 19 \mathrm{H} 32 \mathrm{O} 2$ & 0.76 & PUFA \\
\hline $\begin{array}{l}\text { 9,12-Octadecadienoic acid (Z,Z)-, methyl } \\
\text { ester }\end{array}$ & C19H34O2 & 11.19 & PUFA \\
\hline $\begin{array}{l}\text { 9,12,15-Octadecatrienoic acid, methyl ester, } \\
(\mathrm{Z}, \mathrm{Z}, \mathrm{Z})\end{array}$ & $\mathrm{C} 19 \mathrm{H} 32 \mathrm{O} 2$ & 4.59 & PUFA \\
\hline 7,10,13-Eicosatrienoic acid, methyl ester & $\mathrm{C} 21 \mathrm{H} 36 \mathrm{O} 2$ & 0.81 & PUFA \\
\hline Methyl arachidonate & $\mathrm{C} 21 \mathrm{H} 34 \mathrm{O} 2$ & 3.22 & PUFA \\
\hline Total PUFA - & 23.17 & & \\
\hline
\end{tabular}

Fig.1 Microscopic structure and morphology of $O$. aurita by bright field microscope and scanning electron microscopy (SEM)

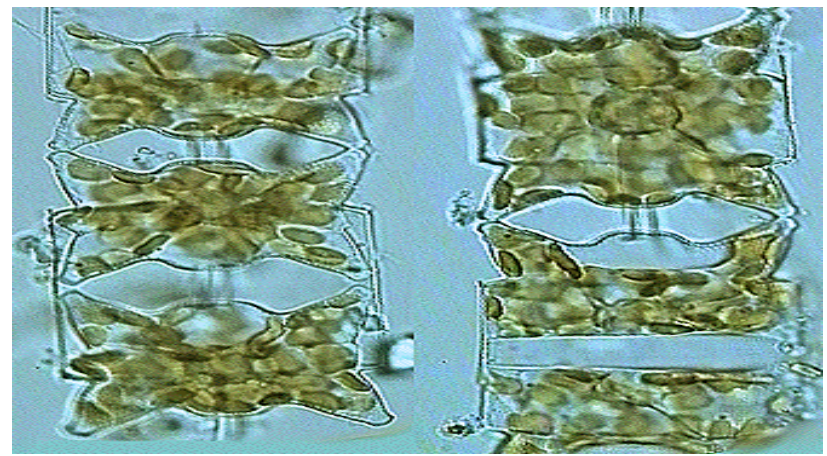

Bight field microscopy

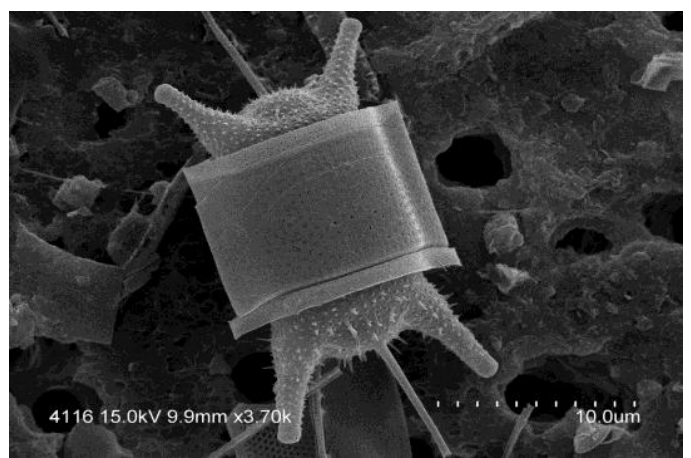

Scanning electron microscopy. 
Fig.2 Growth curve of Odontella aurita at different Si treatment

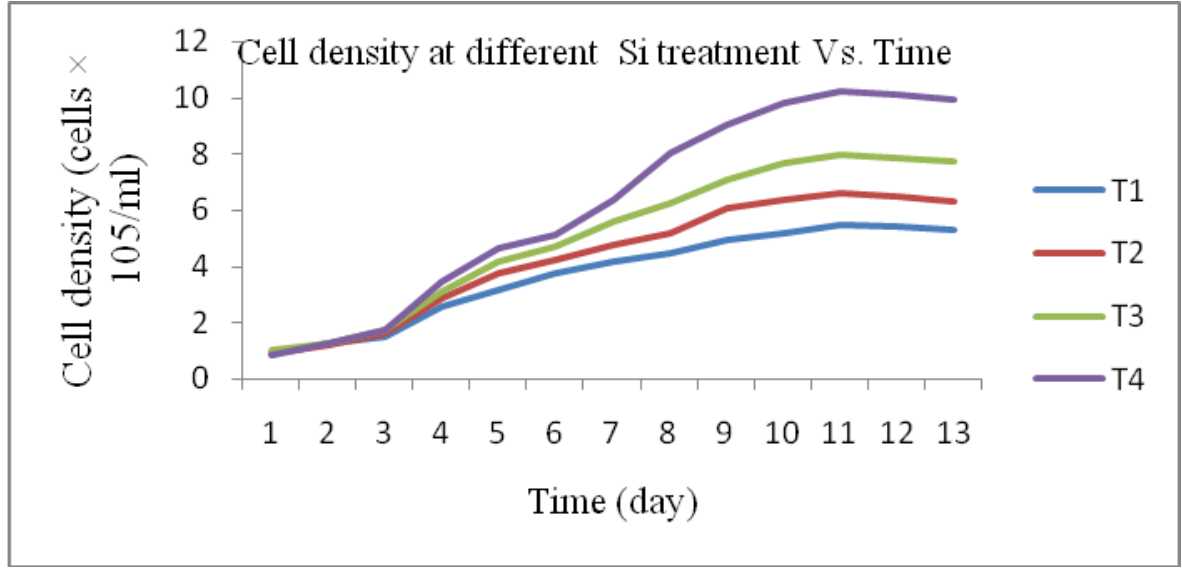

Fig.3 Maximum cell density Odontella aurita at different Si treatment

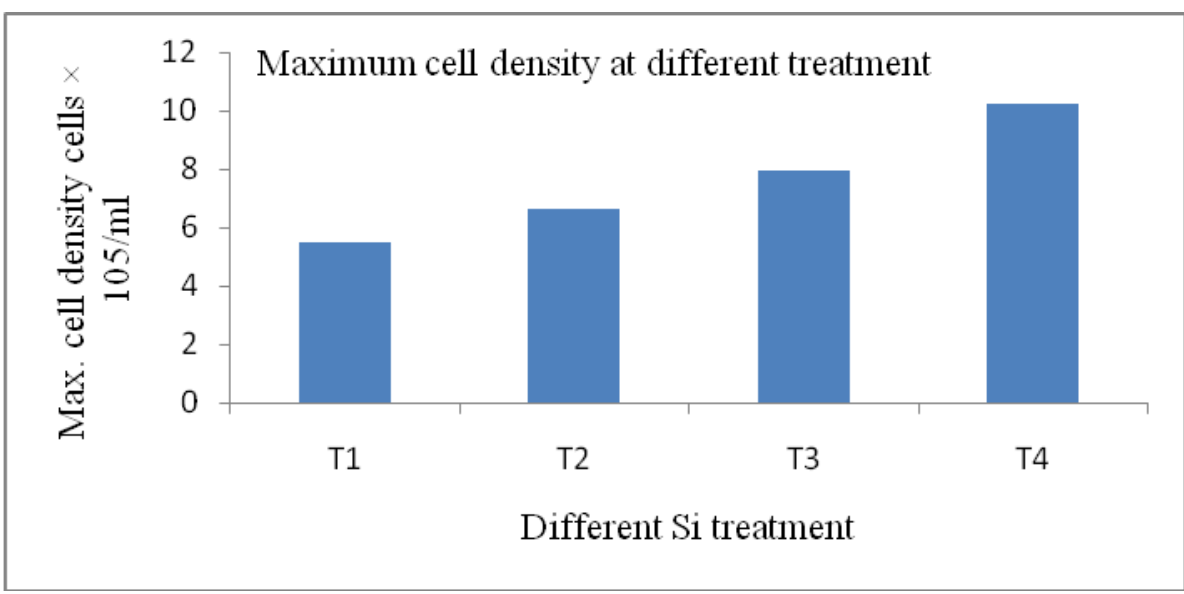

Fig.4 Lipid content (\%) Odontella aurita at different Si treatment

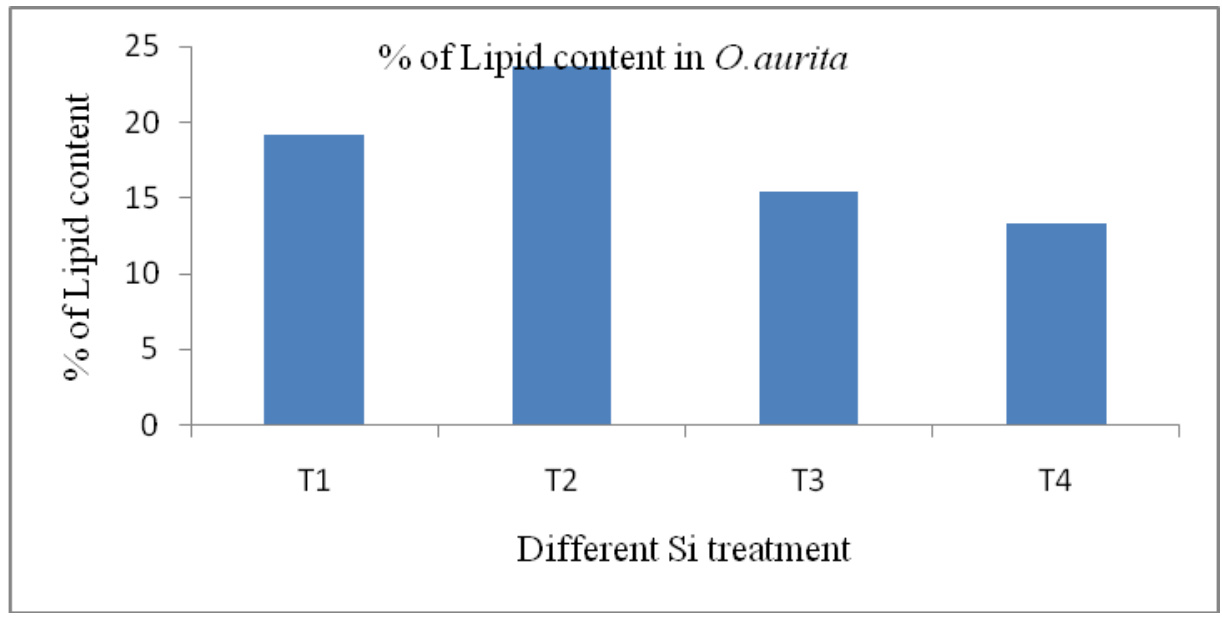


Fig.5 GC-MS chromatogram for FAME analysis

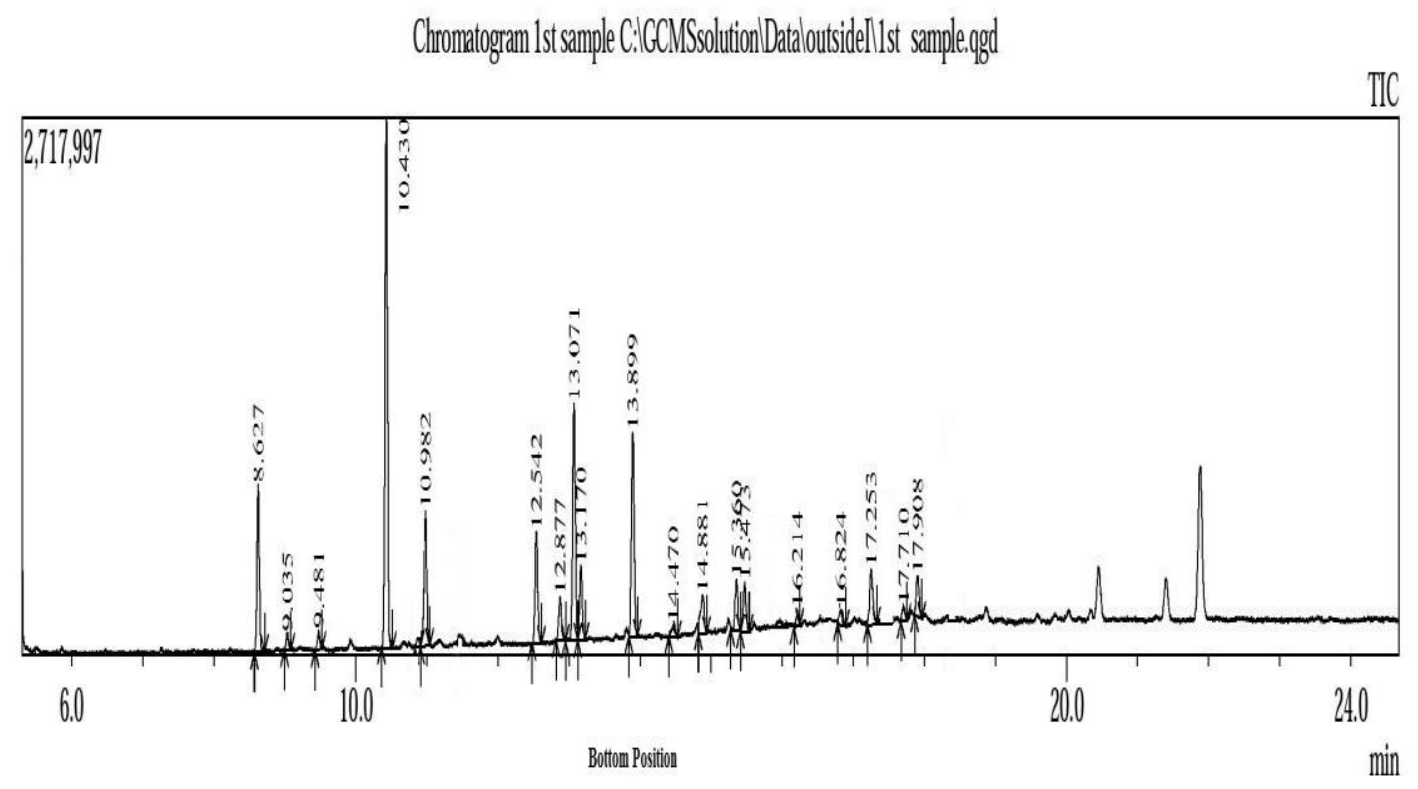

In present study lipid content was found to be maximum $23.70 \pm 0.79 \%$ of dry biomass in treatment $\mathrm{T} 2$ and minimum $13.25 \pm 0.33 \%$ of dry biomass in treatment T4. (Ju et al., 2011) reported in Chaetoceros gracilis that lipid content maximum in Si depletion cell than $\mathrm{Si}$ deficient cell and minimum in Si rich cell. With respect to lipid content, (Shalaby, 2011) evaluated 17 microalgae and found a lipid content ranging from 4 to $40 \%$; while (Andrade-Nascimento et al., 2012) documented the lipids percentage in 12 microalgae species which ranged from 13.52 to $49.0 \%$ and 10 of them had contents from 13.52 to $28.43 \%$ very similar to the values found in the present investigation. (Lee et al., 2011) reported a content of lipids around $15 \%$ for $C$. calcitrans, similar to the found in the present study in the treatment T3 medium (control). Low levels of either sodium chloride or silicon resulted in at least $50 \%$ increases in lipid content (Adams and Bugbee, 2013).

Biodiesel, higher saturated fatty acids with superior oxidative stability and a higher cetane number but rather poor lowtemperature properties. In contrast, polyunsaturated fatty acids have good coldflow properties but are particularly susceptible to oxidation ( $\mathrm{Hu}$ et al., 2008). Low percentage of polyunsaturated fatty acids is very significant for the potential of $O$. aurita for the production of biodiesel (Miao $e t$ al., 2009).

As the fatty acid composition of this study are show in table, this results was similar to as previous study by (Wang et al., 2014), who reported the relative higher percentage of SFAs than PUFA and MUFA (Chen, 2012) reported $41.67 \pm 2.19$ SFA, $25.02 \pm$ 1.32MUFA and $33.33 \%$ PUFA in Cylindrotheca $s p$. Variation in this study may be due change in Si concentration $(53 \mu \mathrm{M})$ in nutrient medium. A large variation in fatty acids was observed between conditions and treatments. Increased the saturated fatty acids and decreased the unsaturated fatty acids with decreased Si concentrations (Jiang et al., 2014). The ratio of unsaturated to saturated fatty acids has been shown to be speciesspecific and affected by abiotic factors (Huerlimann et al., 2010; Renaud et al., 2002). In the diatom Cyclotella cryptica, higher levels of lipid sand higher proportions 
of saturated and mono-unsaturated FAs were produced due to silicon deficiency (Miao and $\mathrm{Wu}, 2006)$. It is essential that the lipid for biodiesel production contains high amount of saturated and monounsaturated fatty acids with low content of polyunsaturated fatty acids (Gao et al., 2013).

In conclusion, the results of the present investigation suggest that $O$. aurita, increased lipid content inclusively in $\mathrm{Si}$ reduced medium $(53 \mu \mathrm{MSi})$. Saturated fatty acids are more abundant than MUFA and PUFA. Based on the above results, it is suggested that $O$. aurita is a possible algal species to be used in biofuel production because of relatively high lipid and saturated fatty acids contents. Thus, additional studies on the fatty acid distribution of $O$. aurita are needed.

\section{Acknowledgement}

Authors would like to thank the authorities of SHIATS, Allahabad and CAS in Marine Biology, Annamalai University, Parangipettai for giving me opportunity for giving necessary facility for completion of the work, author also thankful to ICAR-New Delhi for giving financial support.

\section{References}

Ahmad, A.L., Matyasin, N.H., Derk, C.J.C., Lim, J.K. 2011. Microalgae as a sustainable energy source for biodiesel production: A review. Renewable and Sustainable Energy Reviews, 15(1): 584-59.

Aatola, H., M. Larmi, T. Sarjovaara, and S. Mikkonen. 2008. Hydrotreated Vegetable Oil (HVO) as a Renewable Diesel Fuel: Trade-off between NOx, Particulate Emission, and Fuel Consumption of a Heavy Duty Engine. SAE Int. J. Engine, 1:1251-1262. doi: 10.4271 .
Adams, C. and Bugbee, B. 2013. Enhancing lipid production of the marine diatom Chaetoceros gracilis: synergistic interactions of sodium chloride and silicon. J. Appl. Phycol., DOI 10.1007/s10811-013-0156-7.

Andrade-Nascimento, I., S.S. Izabel-Marques, T.T. Domínguez-Cbanelas, S. AndradePereira, J.I. Druzain, C. Oliveira de Souza, D. Vital Vich, G. Correia de Carvalho and M. Andrade Nacimento, 2012. Screening microalgae strains for biodiesel production: Lipid productivity and estimation of fuel quality based on fatty acids profiles as selective criteria. Bioenerg. Res., 6(1): 1-13. Official Methods of Analysis. 17th Edn.

Borowitzka, M.A. 1988. Fats, oils and hydrocarbons. In M. A. Borowitzka \& L. J. Borowitzka (Eds.), Micro-Algal Biotechnology (pp. 257-287. Cambridge: Press Syndicate of the University of Cambridge.

Chisti, Y. 2007. Biodiesel from microalgae. Biotechnol. Adv., 25: 294-306.

Chen, G. Q., Jiang, Y. and Chen, F. 2007. Fatty acid and lipid class composition of the eicosapentaenoic acid-producing microalga, Nitzschia laevis. Food Chem., 104: 1580-1585.

Chen, YC. 2012. The biomass and total lipid content and composition of twelve species of marine diatoms cultured under various environments. Food Chem., 131: 211-219.

Doan, T.T.Y., Sivaloganathan, B., Obbard, J.P., 2011. Screening of marine microalgae for biodiesel feedstock. Biomass Bioenergy, 35 (7), 2534-2544.

Floch, J., M. Lees and G. H. Sloane-Stanley. 1956. A simple method for the isolation and purification of total lipids from animal tissue. J. Biol. Chem., 226: 497509.

Gao, Y., Yang, M, Wang, C. 2013. Nutrient 
deprivation enhances lipid content in marine microalgae. Biores. Technol., 147: 484-491.

Guillard, R.R.L. 1975. Culture of Phytoplankton for feeding marine invertebrates. Pp26-60. In:Smith, W.L., Chanley, M.H.(Eds), Culture of marine invertebrates animals. Plenum Press, New York. 338pp.

Guschina, I.A. and Harwood, J.I. 2006. Lipids and lipid metabolism in eukaryotic algae. Progress Lipid Res., 45:160-186.

Huerlimann, R., de Nys, R., Heimann, K. 2010. Growth, lipid content, productivity and fatty acid composition of tropical microalgae for scale-up production. Biotechnol. Bioeng., 107(2): 245-257.

Hahn, K.O. 1989. Nutrition and growth of abalone. In K. O. Hahn (Ed.), Handbook of culture of abalone and other marine gastropods (pp. 135-137. Florida: CRC Press Inc.

Hillebrand, H. and Sommer, U. 2000. Diversity of benthic microalgae in response to colonization time and eutrophication. Aquatic Bot., 67: 221236.

Hu, Q., Sommerfeld, M., Jarvis, E., Ghirardi, M., Posewitz, M., Seibert, M., Darzins, A., (2008. Microalgal triacylglycerols as feedstocks for biofuel production: perspectives and advances. Plant J., 54 (4): 621-639.

Hemalatha, A., Karthikeyan, P., Girija, K., Saranya, C., Anantharaman, P., Sampathkumar, P. 2014. Effect of nutrients on the growth and biochemical composition of the marine diatom Chaetoceros simplex (Ostenfeld), 1901. 5(1): 30-35.

Ichihara, K., Shibahara, A., Yamamoto, K., Nakayama, T. 1996. An improved method for rapid analysis of the fatty acids of glycerolipids. Lipids, 31: 535-539.
Jiang, Y., Yoshida, T., Quigg, A. 2012. Photosynthetic performance, lipid production and biomass composition in response to nitrogen limitation in marine microalgae. Plant Physiol. Biochem., 54: 70-77.

Jalal, K.C.A., Shamshuddin, A.A., Rahman M.F., Nurazatul, N.Z. and Rozihan, M. 2012. Growth and total carotenoid, chlorophyll aand chlorophyll $b$ of tropical microalgae (Isochrysis sp.) in laboratory culture condition. J. Biol. Sci., DOI: 3923/jbs.

Ju, Z., Ding, L., Zheng, Q., Wu, Z. and Zheng, F. 2011. Diatoms as a Model System in Studying Lipid Biosynthesis regulation. Int. J. Environ. Sci. Develop., Vol. 2(6).

Kwon, H.K., Oh, S.J., Yang, H.S. 2013. Growth and uptake kinetics of nitrate and phosphate by benthic microalgae for phytoremediation of eutrophic coastal sediments. Bioresour. Technol., 129: 387-395.

Lee, S.J., S. Go, G.T. Jeong and S.K. Kim. 2011. Oil production form five marine microalgae for the production of biodiesel. Biotechnol. Bioproc. E., 16: 561-566.

Lebeau, T. and Robert, J.M. 2003. Diatom cultivation and biotechnologically relevant products. Part II: Current and putative products. Appl. Microbiol. Biotechnol., 60: 624-632.

Miao, X.; Wu, Q. Biodiesel production from heterotrophic microalgal oil. Bioresour. Technol., 97: 841-846.

Mata, T.M., Melo, A.C., Simoes, M. and Caetano, N.S. 2012. Parametric study of a brewery effluent treatment by microalgae Scenedesmus obliquus. Bioresource Technol., 107: 151-158.

Mohan, N., Rajaram, M.G., Boopathy, A.B. and Rengasamy, R. 2012. Biomass and lipid production of marine diatom Amphiprora paludosa W. Smith at 
different nutrient concentrations. $J$. Algal Biomass Utln. 3(4): 52-59.

Renaud, S.M., Thinh, L.V., Lambrinidis, G., Parry, D.L. 2002. Effect of temperature on growth, chemical composition and fatty acid composition of tropical Australian microalgae grown in batch cultures. Aquaculture, 211(1-4): 195214.

Roleda, M.Y., Slocombe, S.P., Leakey, R.J.P., Day, J.D., Bell, E.M., Stanley, M.S. 2013. Effects of temperature and nutrient regimes on biomass and lipid production by six oleaginous microalgae in batch culture employing a two-phase cultivation strategy. Biores. Technol., 129: 439-449.

Ramirez, E.E., Gonzaez, M.A., Cifuentes, A.S., Inostroza, I. and Urrutia, R.E. 2015. Culture and growth of two benthic diatoms species isolated from the Salar del Huasco (North of Chile, $\left.20^{\circ} \mathrm{S}\right)$ at different conditions of temperature, light and nutrient. Gayana Bot. 72(2): 165-176.

Roessler, P.G., Brown, L.M., Dunahay, T.G., Heacox, D.A., Jarvis, E.E, Schneider, J.C. 1994. Genetic-engineering approaches for enhanced production of biodiesel fuel from microalgae. ACS Symp. Ser., 566: 255-70.

Subhramanyan, R. 1946. A systematic account of the marine plankton diatoms of the Madras coast. Proc. Ind. Acad. Sci., 24B: 85-197.
Shalaby, E.A. 2011. Algal Biomass and Biodiesel Production. In: Stoytcheva, M. Ed.), Biodiesel-Feedstocks and Processing Technologies. Intech, Croatia, pp: 111-458.

Subramanian, R., Dufreche, S., Zappi, M., Bajpai, R. 2010. Microbial lipids from renewable resources: production and characterization. J. Ind. Microbiol. Biotechnol., 37:1271-1287.

Tomas, C.R. 1997. Identifying marine phytoplankton. Academic press, California, USA. pp.858.

Venkataraman, G. 1939. A systematic account of some south Indian diatoms. Proc. Ind. Acad. Sci., 10: 293-368.

Vicente, G., Bautista, L.F., Rodriguez, R., Gutierrez, J., Sadaba, I., Ruiz-Vazquez, R.M., Torres-Martinez, S., Garre, V. 2009. Biodiesel production from biomass of an oleaginous fungus, Biochem. Eng. J., 48: 22-27.

Williams, P.J.L., Laurens, L.M.L. 2010. Microalgae as biodiesel and biomass feedstocks: review and analysis of the biochemistry, energetics and economics. Energy Environ. Sci., 3(5): 554-590.

Wang, X.W., Liang, J.R., Luo, C.S., Chen, C.P., Gao, Y.H. 2014. Biomass, total lipid production, and fatty acid composition of the marine diatom Chaetoceros muelleri in response to different CO2 levels. Biores. Technol., 161: $124-130$.

\section{How to cite this article:}

Shailesh Upadhyay, Kapil Lawrence, Sudhir K. Shekhar and Anantharaman, P. 2017. Lipid Screening, Extraction and Production of Biodiesel from Marine Diatom Odontella aurita. Int.J.Curr.Microbiol.App.Sci. 6(3): 1259-1269. doi: https://doi.org/10.20546/ijcmas.2017.603.144 